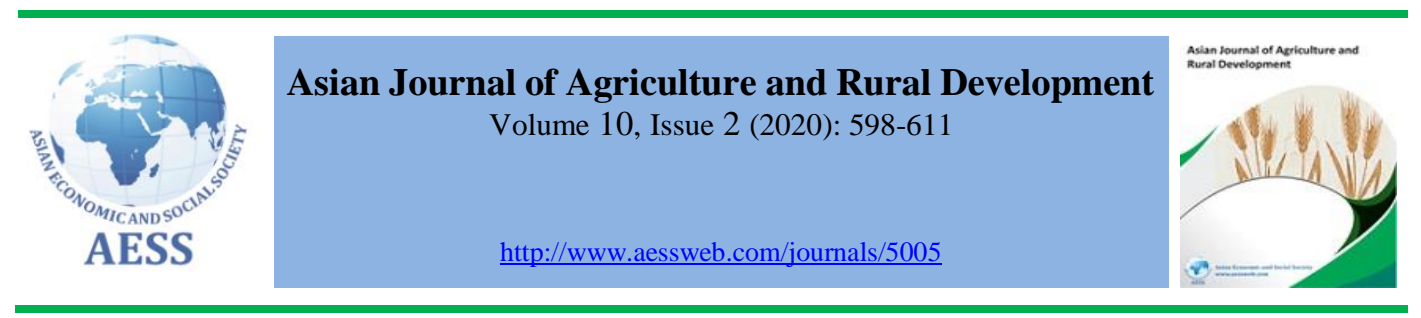

\title{
AGRICULTURAL INTENSIFICATION, DIVERSIFICATION AND MIGRATION AS LIVELIHOOD STRATEGIES AMONG RURAL SCHEDULED TRIBE POPULATION OF PALASBARI REVENUE CIRCLE: A CASE OF INDIA
}

\section{Meghna Das a, \\ Barnali Gogoi ${ }^{\text {b }}$}

\author{
a Ph.D. Scholar; Department of Geography, Cotton University, \\ India \\ ${ }^{\mathrm{b}}$ Associate Professor; Department of Geography, Cotton University, \\ India
}

ه15.dasmeghna@gmail.com (Corresponding author)

\section{ARTICLE HISTORY: \\ Received: $16-\mathrm{Mar}-2020$ \\ Accepted: 28-Jul-2020 \\ Online Available: 27-Aug- 2020}

\section{Keywords:}

Livelihood,

Strategies,

Scheduled tribe

\begin{tabular}{l}
\hline ABSTRACT \\
The key objective of this study is to examine the livelihood practices \\
and strategies adopted by the Scheduled Tribe (ST) population of the \\
Palasbari Revenue circle, Assam, India. For empirical analysis, 132 \\
households were surveyed from 6 areas dominated by the ST \\
population, namely Kallapara N.C. (Satargaon), Jimirigaon, Rani \\
Khamar, Chouthala, Jupangbari, and Kochpara, which aggregates to \\
553 sample populations. It was surveyed by stratified random \\
sampling method from January to March 2020. The results show that \\
livelihood diversification, agricultural intensification and temporal \\
migration are three of the major strategies adopted by the population to \\
meet their needs.
\end{tabular}

\section{Contribution/ Originality}

The importance of the study lies in the diversity of the area, as it has different aspects together, which will help study the diversified nature of human adaptation to its environment overcoming the vulnerabilities and how it evolved and sustained through ages changing their livelihoods accordingly. It is an original study and will be a unique contribution to the existing tribal livelihood literature.

DOI: 10.18488/journal.ajard.2020.102.598.611

ISSN(P): 2304-1455/ ISSN(E): 2224-4433

How to cite: Meghna Das and Barnali Gogoi (2020). Agricultural intensification, diversification and migration as livelihood strategies among rural scheduled tribe population of Palasbari revenue circle: a case of India. Asian Journal of Agriculture and Rural Development, 10(2), 598-611.

(C) 2020 Asian Economic and Social Society. All rights reserved. 


\section{INTRODUCTION}

Livelihood simply means the way of life which involves fulfilling basic needs of life like food, clothing and shelter, which are acquired by the capabilities of people, assets available and income generated (Chambers and Conway, 1992). Geographically, one place differs from another, which leads to the development of different livelihood practices. Through time the population faces varied difficulties in meeting their livelihoods. These difficulties or stresses hinder the smooth functioning of their livelihood practices. For these hindrances, the population adopts certain strategies to meet their needs, which vary from place to place. Such livelihoods that can cope up with difficulties can be called sustainable livelihoods (Scoones, 1998).

Livelihood strategies are the activities performed by the small householders for their social and economic security (Koczberski et al., 2001; Sati et al., 2015). The rural households tend to diversify their income sources as a strategy for survival according to the resources available and within the context of the policy and institutional framework (Ellis, 1998; Barrett et al., 2001; Jansen et al., 2006; Mary et al., 2009; Tittonell et al., 2010; Sati, 2015). Among the livelihood strategies, agricultural intensification is another key strategy adopted by the rural population in different parts of the world (Scoones, 1998; Ellis, 2000; Sati et al., 2015). Through decades there developed numerous poverty reduction or eradication goals and goals for sustainable development worldwide such as Millennium Development Goals (2000-2015) and Sustainable Development Goals (2015-2030) which also focuses the rural population and their sustainability indirectly aiming for the livelihood sustainability of these folks (Brocklesby and Fisher, 2003). During this period several sustainable livelihood approaches emerged consistently from varied parts of the world with different perspectives (Farmer, 1977; Walker and Ryan, 1990; Chambers and Conway, 1992; Moser, 1998; Carney, 1998, 2002; Ashley and Carney 1999; Gieryn, 1999; Brocklesby and Fisher, 2003). In the years 1987 and 1992, two forums that is World Commission on Environment and Development (WCED) and UN Conference on Environment and Development respectively emphasized on the livelihoods around the world and its linkage with the environment was focused and policies were framed accordingly (WCED, 1987; Conroy and Litvinoff, 1988; Brocklesby and Fisher, 2003).

Globally, about $60 \%$ of the developing countries' populations are classified as rural and of which about $85 \%$ are still dependent on agriculture (Dixon et al., 2001). In India, about 68.84\% (Chandramouli, 2011) people live in rural areas, of which about $70 \%$ of the rural population are still dependent on agriculture primarily (FAO, 2020). Agriculture is the largest livelihood source along with its allied activities globally as well as in India.

India is a hub of the world's largest tribal population (India Today, 2017). According to the 2011 census, the tribal population in India is 10.43 crore, which consists of $8.6 \%$ of the total population of the country and this $89.97 \%$ lives in rural areas (Statistical Profile of Scheduled Tribes in India, 2009). The Scheduled Tribes always have an intrinsic and interactive relationship with the environment they live in. They depend on nature to acquire necessities for living. Dependence of village dwellers on wild natural resources for consumption in times of emergency is reported extensively (Byron and Arnold, 1999; Neumann and Hirsch, 2000; FAO, 2008; Belchar et al., 2015). According to Dube, a tribe is generally referred to communities that have been living in isolation from the mainstream population since the historical past; as a result, they have developed separate cultural identities and traditions which vary from other peoples (Tribal Community Development, 2020).

Assam is a state with different tribal groups. Kamrup district of Assam state has a total population of 1517542 persons, out of which 11.99\% (182038 persons) are Scheduled Tribe (ST) population (Census, 2011). The Palasbari Revenue circle of Kamrup district comprises $16.47 \%$ (39369 persons) of ST population. The district is topographically diversified, and so are the livelihoods. 
The ST population has different vulnerabilities in attaining their livelihoods, so they have to adopt different strategies to overcome these hurdles through time.

\section{THE STUDY AREA}

The study is carried out in the Palasbari Revenue circle located in Kamrup District of Assam. Palashbari Revenue circle is one of the 12 Revenue circles of Kamrup district. The Revenue Circle has a dense forest in some parts, the mighty river Brahmaputra flowing through it, the Chandubi Lake, in addition to the vast alluvial agricultural fields. It shares a boundary with Kamrup Metro district and is located at a distance of about $22 \mathrm{~km}$ from Guwahati city. Human adaptation to this diversified natural environment overcoming vulnerabilities like conflicts with animals, natural hazards in the form of flood, etc. and evolving and sustaining through ages changing their livelihoods is a subject of worth exploring. Due to the diverse environmental and situational conditions, Palasbari Revenue Circle is selected for the present study.

As it is shown in Figure 1 the study area lies within the geographical coordinates $25^{\circ} 50^{\prime} 23^{\prime \prime} \mathrm{N}$ to $26^{\circ} 10^{\prime} 26^{\prime \prime} \mathrm{N}$ latitudes and $91^{\circ} 19^{\prime} 12^{\prime \prime} \mathrm{E}$ to $91^{\circ} 43^{\prime} 38^{\prime \prime} \mathrm{E}$ longitudes. It covers a total area of $659.12 \mathrm{~km}^{2}$. The study area comprises of 182 villages and eight urban areas, out of which Scheduled tribe populations are distributed in 116 villages and eight urban areas (Census 2011). The study is carried out among 132 sample households from 5 sample villages and one urban area comprising 553 sampled population dominated by ST people, namely Kallapara N.C. (Satargaon), Jimirigaon, Rani Khamar, Chouthala, Jupangbari and Kochpara Census Town (CT).

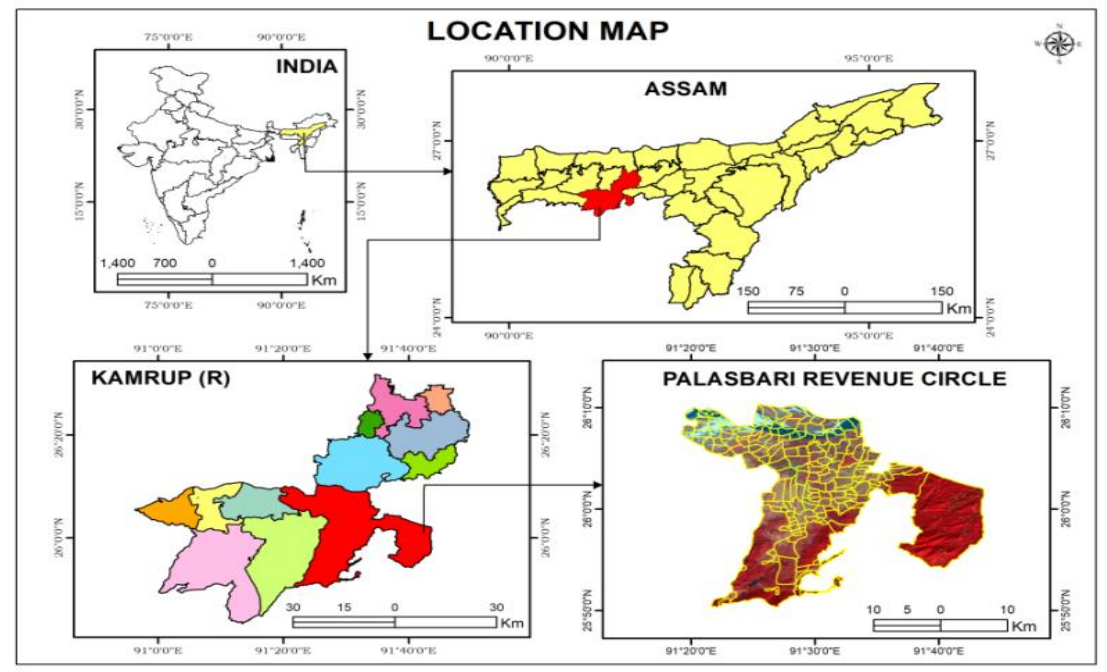

Figure 1: Location map of the study area

\section{METHODOLOGY}

The key objective of the study is to examine the livelihood practices and strategies adopted by the population; hence it is mainly based on primary data collected from the study area through field visits. Before going to the field for a survey, the sample villages were selected from the secondary Census data available for the 2011 year. For that, $5 \%$ of ST villages are selected from the total ST villages of the revenue circle, which resulted in 5 sample ST villages and one urban area. These five villages and one urban area have the highest ST population in the study area, respectively, for both rural and urban areas. After that, $30 \%$ of households from each of these villages are selected as sample for this study. This $30 \%$ of surveyed households have a total population of 553 persons. The 
Taro Yamane formula is used for the population sample. According to Taro Yamane formula (Yamane, 1973) for determining sample size at 0.05 (95\% confidence level) margin of error, the sample population in our study area should be 396 persons. But as the targeted population group is found mixed with other groups of the population, we had first to select the sample areas. In applying stratified random sampling, the total population surveyed becomes 553 persons.

Taro Yamane (Yamane, 1973) formula:

$$
n=N / 1+N\left(e^{2}\right)
$$

Where

$n=$ correlated sample size, $N=$ population size and $e=$ Margin of Error (MoE)

For primary data collection, a structured survey schedule is prepared beforehand. During the field study, data related to their lifestyle, education, economy, language, religion, etc. were collected through the survey schedule and personal observation. After the data collection, it was analyzed in IBM SPSS 21 software and thematic maps related to the study were prepared in a GIS environment.

\section{RESULTS AND DISCUSSION}

\subsection{Assets of the study area}

Assets are the key ingredients in the whole livelihood process. According to King (2011), livelihood production is based on several elements, also known as capitals. These are prominently categorized into five categories: economic/financial, human, natural, social, and physical. Sallu et al. (2010) highlighted that vulnerability among households can be reduced by providing access to diverse assets.

\subsubsection{Economic}

Land is an important asset, both economically and environmentally, in a global context. According to Ullah et al. (2019), ownership of land affects farmers indirectly by giving them the power to take risk management decisions. It acts as a resource for the rural population in terms of livelihood practices. As $57.6 \%$ of the surveyed populations in our study area are directly dependent on onfarm activities, land resource plays a prominent role in the livelihood system of the rural population. The mainstay of the surveyed population is agrarian. The total land resource available to the surveyed household is 160.05 ha. Based on occupancy and land use, these may be categorized into different types. Out of the total land, 149.16 ha are owned by the surveyed households, and the rest are adhiya (10.89 ha). According to the use of land, 98.49 ha are cultivated land (87. 60 ha are own land and 10.89 are Adhiya land), 49.83 ha are homestead and 12.18 ha is fallow land. These lands were mostly inherited $(63.6 \%)$ by the population from their parents or ancestors. Due to land division through generation, the inherited land size kept on decreasing and as a result, the poorest section of the population rents or takes adhiya $(31.1 \%)$ from some other households for cultivation. Similarly, $0.8 \%$ of households who purchased land and $4.5 \%$ of households who inherited plus purchased land belong to the urban area of the revenue circle (Table 1). The average landholding size is 1.21 ha per household. The maximum landholding size is 6.26 ha of a family in Jimirigaon village.

Table 1: Mode of land acquisition

\begin{tabular}{lcc}
\hline Mode of Land acquisition & Frequency & Valid Percent \\
\hline Inherited & 84 & 63.6 \\
Purchased & 1 & 0.8 \\
Both Inherited \& Rented & 41 & 31.1 \\
Both Inherited \& purchased & 6 & 4.5 \\
Total & 132 & 100.0 \\
\hline
\end{tabular}

Source: Survey data, 2019 


\subsubsection{Human}

The surveyed sample villages have a total population of 9471 persons residing in 2114 households (Census, 2011). All the sample villages have 100\% Scheduled Tribe population except for Kochpara (CT), which has a $1.72 \%$ ST population and also the only urban sample area (Census, 2011). The total number of households surveyed is 132, with a population of 553; out of it, $52.8 \%$ are males and $47.2 \%$ are females. Of the total population, $64.91 \%$ (359 persons) form the workforce. The highest percentage of the population (31.6\%) has education up to High School/ Higher Secondary level in both males $(36.7 \%)$ and female $(25.7 \%)$ category. The percentage of the population with higher education is very low $(4.5 \%)$, of which $3.3 \%$ is graduate, $0.4 \%$ is postgraduate, and the remaining $0.8 \%$ have skilled education (Table 2). The school dropout rate is $2.2 \%$. The total illiteracy rate is $16.3 \%$, of which male illiteracy is $8.4 \%$, and female illiteracy is $25.3 \%$. It shows high illiteracy and low level of education among the females. The ST population surveyed belongs to Bodo and Rabha tribes.

Table 2: Sex wise distribution of level of education

\begin{tabular}{lcccccc}
\hline Education level of the Individuals & $\begin{array}{c}\text { Male } \\
(\mathbf{N o})\end{array}$ & $\begin{array}{c}\text { Male } \\
(\boldsymbol{\%})\end{array}$ & $\begin{array}{c}\text { Female } \\
(\mathbf{N o})\end{array}$ & $\begin{array}{c}\text { Female } \\
(\boldsymbol{\%})\end{array}$ & $\begin{array}{c}\text { Total } \\
(\text { No. })\end{array}$ & $\begin{array}{c}\text { Total } \\
(\%)\end{array}$ \\
\hline Primary education (Class 1-5) & 79 & 28.7 & 68 & 28.2 & 147 & 28.5 \\
Secondary education (Class 6-8) & 55 & 20.0 & 44 & 18.3 & 99 & 19.2 \\
High school (Class 9-10)/Higher & 101 & 36.7 & 62 & 25.7 & 163 & 31.6 \\
Secondary (Class 11-12) & 17 & 6.2 & 6 & 2.5 & 23 & 4.5 \\
Higher Education & 23 & 8.4 & 61 & 25.3 & 84 & 16.3 \\
Illiterate & 275 & 100 & 241 & 100 & 516 & 100 \\
Total & & & & & & \\
\hline
\end{tabular}

Source: Primary survey

The level of education is a strong determinant of occupational activities and livelihood practices. The more an individual is educated, the more is his /her chance to get a job, which is not possible in case of a less educated person. From the above table, it is clear that only $4.5 \%$ population has higher education, which indicates less scope to get a secure job or livelihood source for most of the surveyed population. Moreover, only $2.5 \%$ of females have a higher education, which depicts the sad reality of women's education. The populations with a low level of education have to develop certain strategies of livelihood to survive and sustain during shocks and stresses. The village population is also skilled in different traditional activities like weaving clothes, traditional beer making, bamboo crafts, etc.

\subsubsection{Natural}

Forest plays a vital role in human life. According to Zenteno et al. (2013), fringe rural populations specifically of the tropical forest areas are highly, directly, or indirectly dependent on the forest resources for income generation. In addition to that, an ecosystem-based adaptation of the people offers support to their livelihood strategies and increase social empowerment (Woroniecki et al., 2019). As all the five villages and the one urban area are located near reserved forests, they have accessibility to natural resources. The five villages are highly dependent on their neighboring reserved forests for food and fuel. They collect varieties of tubers, leafy vegetables, wild mushrooms, medicinal plants, fruits, bamboo, fuelwood, etc. from the forests daily for their livelihood. In addition to that, all the five villages also collect faunal species from the existing streams, lakes, ponds and agricultural fields in their locality. This level of dependence on natural assets is not observed among the urban population.

\subsubsection{Social}

The surveyed population has a strong social bond. Every five villages have multiple Self Help Groups (SHG) and village societies for monetary transactions among their group members and also 
outside the members. It creates a good network among the villagers and, in time of needs, can borrow money from these societies. These groups are mainly created and maintained by the female section. However, in Kallapara N.C. (Satargaon) a group is formed among the male section for fishery maintenance. The formation of such a group is observed less among the urban population. Though a few households in the urban area are members of such groups, the amount of money deposited varies from the rural population. The rural people being poor and less educated (especially the women) cannot afford to deposit a larger amount of money at a time.

\subsubsection{Physical}

The roads in all the surveyed villages are observed to be in good condition irrespective of its location. Electricity connection is available in all the villages and urban areas except for Kallapara N.C. (Satargaon) which is a forest village. But one NGO provides solar panels to each of the households of Satargaon, which is quite satisfactory for the villagers. Government Primary schools are located in each of the villages. But Medical centers and sub-centers are not available in each of these villages, while the urban area has all the physical assets available within their locality.

\subsection{Problems in attaining livelihood}

The six sampled areas are distributed in different corners of the revenue circle (Fig 2c). Almost all the sample areas are located at the edge of a reserve forest, but their livelihood practices and related problems and benefits are different.

\subsection{Transport and accessibility}

Kochpara (CT), which is located in the urban area, has the maximum benefits related to the availability of transport and communication, and is highly accessible. At the same time, Chouthala is moderately accessible as public transport is available from time to time and as it is located near the main road connecting NH 37. On the other hand, accessibility is very low in Japangbari, Jimirigaon and Rani Khamar. Japangbari is located at a distance of about 5-6 km from the main road that connects to the NH 37. In contrast, Jimirigaon and Rani Khamar are located at the remote Assam- Meghalaya border. Kallapara N.C. (Satargaon) is a forest village thus no public transport is available in the village and the villagers have to travel $7 \mathrm{~km}$ to the main road where public transports are available. Due to less accessibility and poor transportation Japangbari, Kallapara N.C., Jimirigaon and Rani Khamar are lagging in terms of education and economy and have less access to health services.

\subsection{Education and medical facilities}

Just like transport and communication Kochpara (CT) has high accessibility of medical and education facilities among the surveyed villages as it is an urban area and located near NH 37. Apart from it, all the other surveyed villages have primary schools within the village and medical facilities within 1-7 km distance for basic health issues. But higher education facilities are less accessible to all the villages. Similar is the case in medical facilities; for specialized treatment or better health facilities, the villagers have to travel either to urban areas of the revenue circle or to Guwahati city. Therefore, for a higher level of education and medical treatments, the villagers have to migrate to the urban areas temporarily.

\subsection{Occupation and natural dimensions}

In Kochpara Census town, the main source of livelihood of the maximum sampled household is government service. So the population doesn't face many difficulties in attaining their livelihoods. Natural constraints are also less in this Census Town compared to the rural areas. Above that, there is no such natural severe problem which is faced by this Census town.

Contrary to that, the village Satargaon located in Kallapara N.C. which is a forest village, faces a lot of vulnerabilities in terms of meeting their day to day livelihoods. The wild elephants residing within the Rani Reserve Forest roam in and around the village, which hinders the villagers' 
movement during night time. Moreover, due to the occurrence of such incidents frequently, most of the villagers' quitted the cultivation of rice 10-15 years ago. Similar conflicts with wild elephants are also observed in the other sample villages but lesser intensity. In addition to that, very few villagers of these villages are engaged in government jobs, most of them are dependent on farmbased activities.

For these vulnerabilities or problems like small landholding size, low level of education, conflicts with animals, lack of transportation facilities faced by the population in achieving their livelihoods, have compelled them to adopt strategies for a bit better lifestyle.

a.

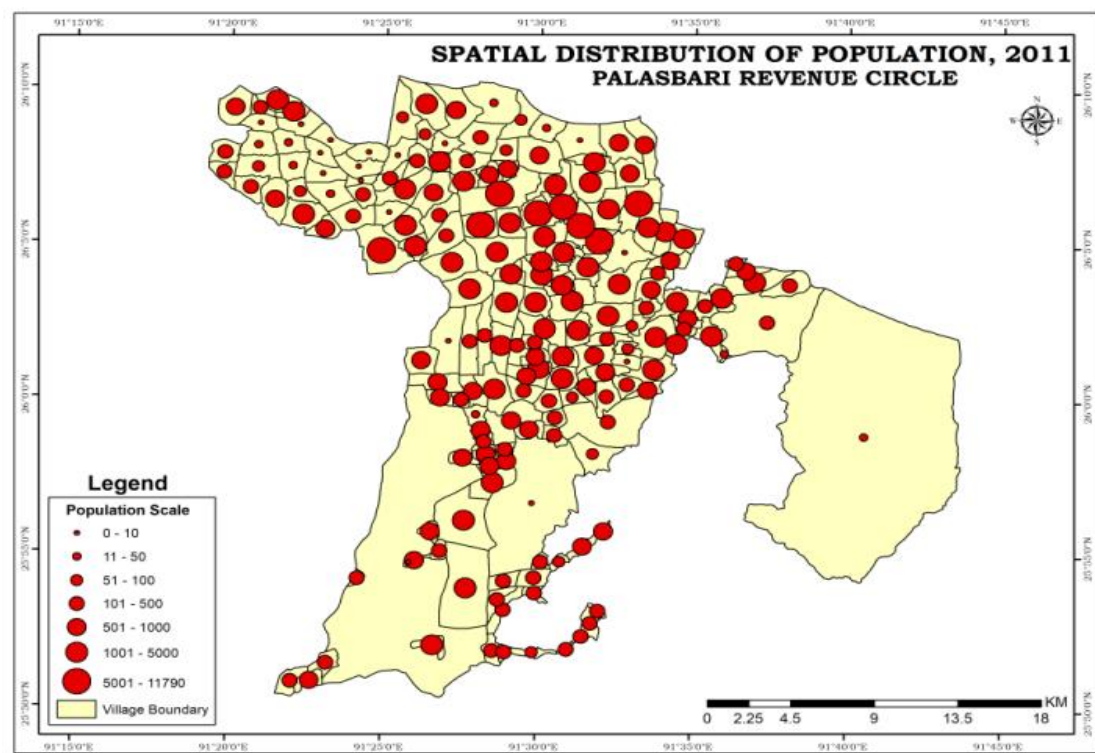

b.

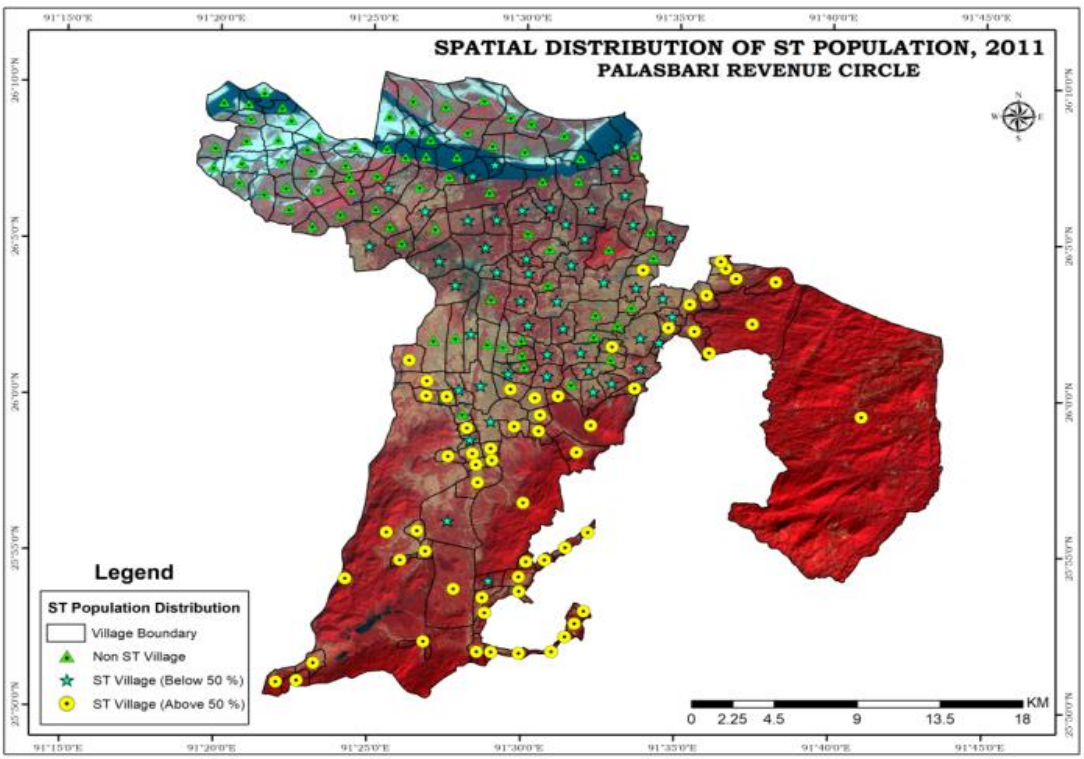


c.

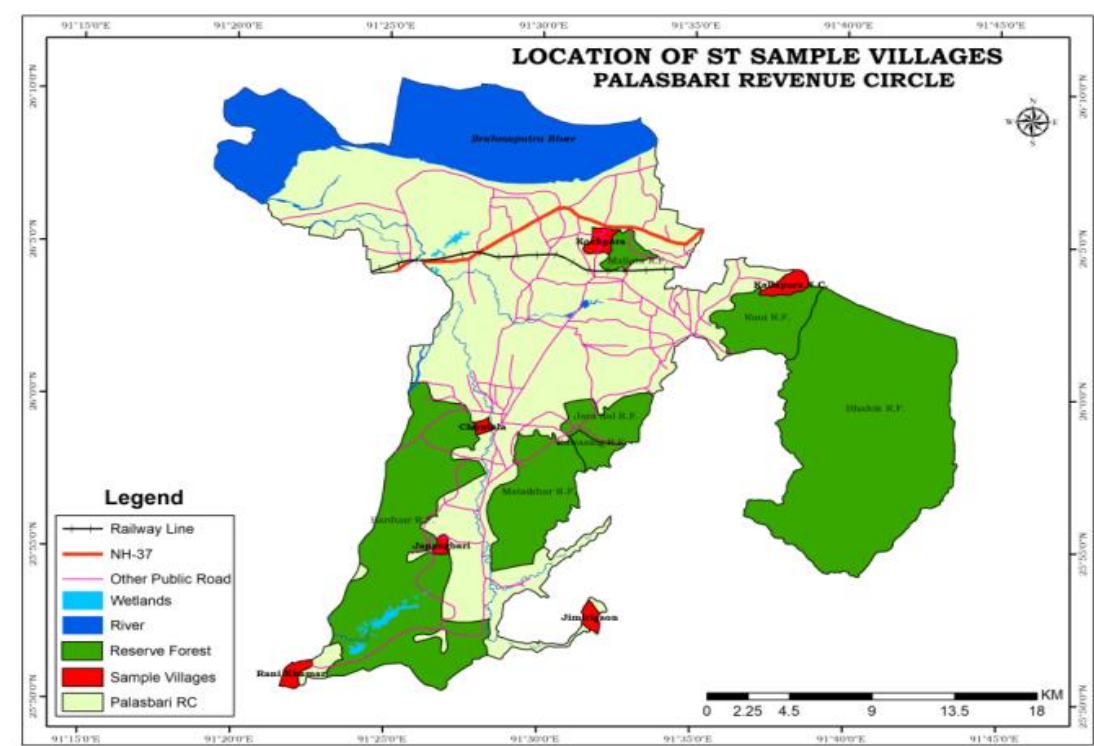

Figure 2: Spatial distribution of a). Population, b). Villages with ST population and c). Sample villages

\subsection{Livelihood practices and strategies}

\subsubsection{Agricultural intensification}

According to a study carried by Diniz et al. (2015) found that the future perception of Brazilian small farmers are that agricultural activities (both livestock and crop production), policy effectiveness, pensions and subsidies will affect livelihood security and environmental sustainability the most in their area. From the surveyed data of our study area, it is found that about $57.6 \%$ of the households are directly dependent on farm activities and $42.4 \%$ of households are dependent on off-farm activities, which include daily wage labor, petty business, jobs, etc. (Table 3 ). So it can be said that the majority of the population are agrarian and their livelihood is agriculture-related. The farm and off-farm activities are again sub-divided into details to get a clear picture of livelihood practices (Table 4). The highest percentage (43.2) of households is involved in paddy farming, which indicates the utmost dependence of the rural ST population on it. In addition to that, among the surveyed population, about $49.2 \%$ of the households practice agriculture traditionally, $26.5 \%$ use modern methods for cultivation, $11.4 \%$ use both traditional and modern methods (Table 5). The traditional methods include organic cultivation without applying any chemical pesticides, using traditional farm implements, and animate energy to plow the soil. The modern method includes the application of chemical pesticides and the use of power tiller and tractor to maximize food production in a limited area in less time. Thus these farmers had adopted agricultural intensification as a strategy to increase the production of crops.

Table 3: Primary occupation of the households

\begin{tabular}{lcc}
\hline Primary occupation & Households & Valid Percent \\
\hline Farm & 76 & 57.6 \\
Off- farm & 56 & 42.4 \\
Total & 132 & 100.0 \\
\hline
\end{tabular}

Source: Survey data, 2019 
Table 4: Additional livelihood activities of the households

\begin{tabular}{lcc}
\hline Livelihood activities & Households & Valid Percent \\
\hline Paddy Farming & 57 & 43.2 \\
Agricultural laborer & 2 & 1.5 \\
Daily wage earner & 10 & 7.6 \\
Private sector wage earner & 7 & 5.3 \\
Government permanent job & 11 & 8.3 \\
Vegetable seller & 7 & 5.3 \\
Petty business & 11 & 8.3 \\
Pension & 4 & 3.0 \\
Construction worker & 3 & 2.3 \\
Carpentry & 1 & .8 \\
Private job & 3 & 2.3 \\
Government contractual job & 4 & 3.0 \\
Plantation & 11 & 8.3 \\
Sand Business & 1 & .8 \\
Total & 132 & 100.0 \\
\hline
\end{tabular}

Source: Survey data, 2019

Table 5: Paddy cultivation methods

\begin{tabular}{lcc}
\hline Paddy cultivation methods & Households & Valid Percent \\
\hline Traditional & 65 & 49.2 \\
Modern & 35 & 26.5 \\
Both & 15 & 11.4 \\
No agriculture & 17 & 12.9 \\
Total & 132 & 100.0 \\
\hline
\end{tabular}

Source: Survey data, 2019

\subsubsection{Migration}

As shown in Table 6, the surveyed populations have adopted temporal and permanent migration as a strategy for livelihood. Due to a lack of income opportunities and better facilities in their original villages, 27 households in a combination of other strategies have considered migration for better opportunities and facilities. The nine households who have permanently migrated to the urban areas of Kochpara ward are engaged in permanent government services. They have migrated permanently to avail of all the facilities of urban areas that are not available in the original remote villages. The temporal migration within Assam and outside Assam (like Kerela, Hyderabad, etc.) is followed mainly by the young population who work as daily wage earners in factories and other private sector companies. Due to poverty and lack of income generation opportunities in their locality, these people are attracted to such private sectors.

\section{Table 6: Strategy adopted by each household}

\begin{tabular}{lcc}
\hline Strategy & Household & Valid Percent \\
\hline Diversification & 69 & 52.3 \\
Permanent Migration & 1 & 0.8 \\
Agricultural Intensification & 14 & 10.6 \\
Diversification and Agricultural intensification & 22 & 16.7 \\
Diversification and Temporal Migration & 12 & 9.1 \\
Diversification, Temporal Migration and Agricultural intensification & 4 & 3.0 \\
Permanent migration and agricultural intensification & 8 & 6.1 \\
Temporal migration and agricultural intensification & 2 & 1.5 \\
Total & 132 & 100.0 \\
\hline
\end{tabular}

Source: Survey data, 2019 


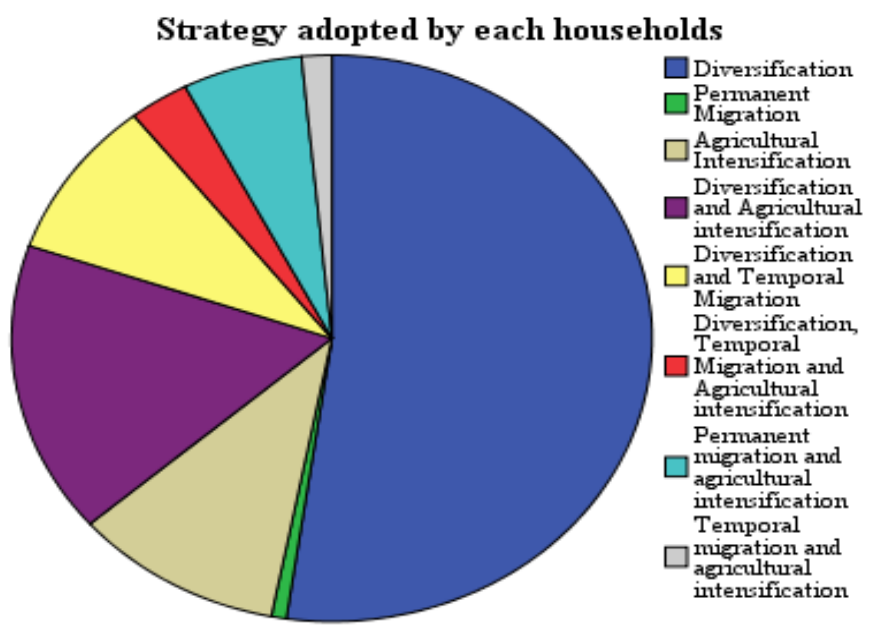

Figure 3: Strategies adopted by each household

\subsubsection{Diversification}

From Table 6, it is clear that livelihood diversification (52.3\%) alone is the most followed strategy by the surveyed households in different intensities. In combination with other strategies, it is followed as a complementary strategy by 107 households $(81.06 \%)$. Moreover, the livelihood diversification is observed more among the Below Poverty Line (BPL) and AAY (Antyodaya Anna Yojana) ration cardholder households. This is because these poor sections of the population have to change their income source seasonally as they don't have a permanent income source to meet their needs. Similar results were also found by Oyinbo et al. (2016) that livelihood diversification increases the level of income of the farmers and safeguards them in an extreme crop failure period. About $75 \%$ of Above Poverty Line (APL) households have 1-3 income sources, which is least diversified and more specialized. In contrast to that, about $85.7 \%$ of BPL households and $14.3 \%$ of AAY households have 7-9 income sources annually. In all, 83 households have 4-6 income sources per year (Table 7). The diversification of livelihood is also dependent on the number of family members. Family size is a crucial determinant of the level of poverty (Oyinbo et al., 2016). Poverty increases in the case of a bigger family and it is tried to compensate through diversification. As observed in Table 8, 39.3\% of households with 1-3 family members have about 1-3 income sources in a year, whereas $9.5 \%$ of households with family members nine and above have 7-9 income sources per year. It shows that the more the family members, the more is the need as well as the workforce and so the livelihood diversification increases accordingly to feed the family properly throughout the year.

Table 7: Cross-tabulation between livelihood diversification per household and type of ration card

\begin{tabular}{|c|c|c|c|c|c|c|}
\hline \multirow{2}{*}{\multicolumn{2}{|c|}{$\begin{array}{l}\text { Livelihood diversification per } \\
\text { household }\end{array}$}} & \multicolumn{4}{|c|}{ Ration card type } & \multirow{2}{*}{ Total } \\
\hline & & APL & BPL & No card & AAY & \\
\hline \multirow{2}{*}{$\begin{array}{l}\text { Household with 1-3 } \\
\text { income source }\end{array}$} & Count & 21 & 5 & 2 & 0 & 28 \\
\hline & Percentage & $75.0 \%$ & $17.9 \%$ & $7.1 \%$ & $0.0 \%$ & $100.0 \%$ \\
\hline \multirow{2}{*}{$\begin{array}{l}\text { Household with 4-6 } \\
\text { income source }\end{array}$} & Count & 23 & 50 & 10 & 0 & 83 \\
\hline & Percentage & $27.7 \%$ & $60.2 \%$ & $12.0 \%$ & $0.0 \%$ & $100.0 \%$ \\
\hline \multirow{2}{*}{$\begin{array}{l}\text { Household with 7-9 } \\
\text { income source }\end{array}$} & Count & 0 & 18 & 0 & 3 & 21 \\
\hline & Percentage & $0.0 \%$ & $85.7 \%$ & $0.0 \%$ & $14.3 \%$ & $100.0 \%$ \\
\hline \multirow{2}{*}{ Total } & Count & 44 & 73 & 12 & 3 & 132 \\
\hline & Percentage & $33.3 \%$ & $55.3 \%$ & $9.1 \%$ & $2.3 \%$ & $100.0 \%$ \\
\hline
\end{tabular}

Source: Survey data, 2019 


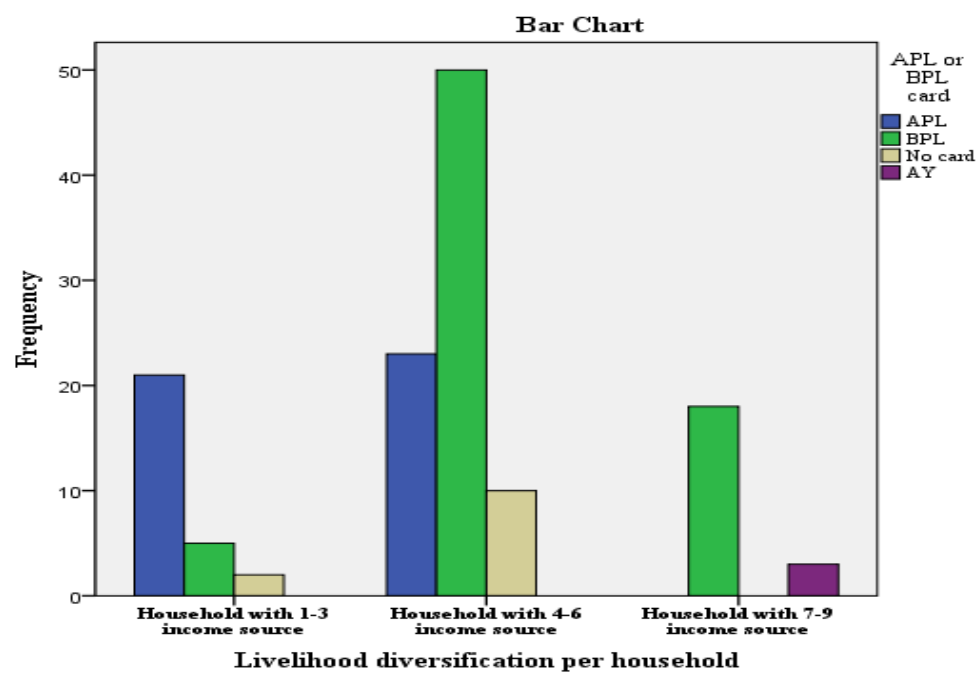

Figure 4: Relationship between livelihood diversification per household and Ration card type

Table 8: Cross-tabulation between livelihood diversification per household and number of family members

\begin{tabular}{|c|c|c|c|c|c|c|c|}
\hline \multirow{2}{*}{\multicolumn{3}{|c|}{ Livelihood diversification per household }} & \multicolumn{4}{|c|}{ Total family members } & \multirow[b]{2}{*}{ Total } \\
\hline & & & $\begin{array}{c}1-3 \\
\text { member }\end{array}$ & $\begin{array}{c}\text { 4-6 } \\
\text { member }\end{array}$ & $\begin{array}{c}7-9 \\
\text { member }\end{array}$ & above 9 & \\
\hline \multirow{6}{*}{$\begin{array}{l}\text { Livelihood } \\
\text { diversification } \\
\text { per household }\end{array}$} & $\begin{array}{l}\text { Household } \\
\text { with 1-3 }\end{array}$ & Count & 11 & 17 & 0 & $\overline{0}$ & 28 \\
\hline & $\begin{array}{l}\text { income } \\
\text { sources }\end{array}$ & $\%$ & $39.3 \%$ & $60.7 \%$ & $0.0 \%$ & $0.0 \%$ & $100.0 \%$ \\
\hline & Household & Count & 22 & 60 & 1 & 0 & 83 \\
\hline & $\begin{array}{l}\text { witn 4-0 } \\
\text { income } \\
\text { sources }\end{array}$ & $\%$ & $26.5 \%$ & $72.3 \%$ & $1.2 \%$ & $0.0 \%$ & $100.0 \%$ \\
\hline & $\begin{array}{l}\text { Household } \\
\text { with } 7-9\end{array}$ & Count & 0 & 16 & 3 & 2 & 21 \\
\hline & $\begin{array}{l}\text { income } \\
\text { sources }\end{array}$ & $\%$ & $0.0 \%$ & $76.2 \%$ & $14.3 \%$ & $9.5 \%$ & $100.0 \%$ \\
\hline \multicolumn{2}{|l|}{ Total } & $\begin{array}{l}\text { Count } \\
\%\end{array}$ & $\begin{array}{c}33 \\
25.0 \% \\
\end{array}$ & $\begin{array}{c}93 \\
70.5 \% \\
\end{array}$ & $\begin{array}{c}4 \\
3.0 \% \\
\end{array}$ & $\begin{array}{c}2 \\
1.5 \% \\
\end{array}$ & $\begin{array}{c}132 \\
100.0 \% \\
\end{array}$ \\
\hline
\end{tabular}

Source: Survey data, 2019

\section{CONCLUSION}

This study focused on the livelihood practices and strategies adopted by the Scheduled Tribe population of the Palasbari Revenue Circle. The study shows that the Scheduled Tribe population (above $50 \%$ ST population) is mainly distributed in the Assam-Meghalaya border areas, and few are located in other rural and urban areas of the revenue circle. There are several assets available to the rural Scheduled Tribe population of Palashbari revenue circle of Kamrup district but minimally. Forest is an essential natural asset available to the people, but they are allowed to extract only the minor products of it as it is a Reserved Forest. Therefore significant economic activity like logging is not possible for them. This natural asset acts as a means of supplementary livelihood activities of the neighboring people. The land is the most important asset for this agricultural community. But this asset is inherited one and due to the nature of inheritance as in other parts of the country the 
landholding size has become too small to support a family, average landholding size being only 1.21 ha per family. So agricultural intensification is dominant as a strategy among the studied population. It shows the importance of agriculture in the study area. The only resource/asset abundant with them is the human resource that too is in quantity only, not in quality, as revealed by the level and kind of education. Therefore to sustain their lives, the Scheduled Tribe population of the study area has used this asset to diversify economic activities. These economic activities are again determined by the quality of the manpower. As a result, these activities are diverse, seasonal, or temporary. More diversification is observed in the case of poor and large family and irregular jobs, while diversification is less in the case of families with secure jobs. However, social networking, particularly among the females, at the initiative of the government, has been introduced in the study area. Through time they have got adapted to these vulnerabilities and hindrances and adopted different strategies to fulfill their day to day life needs. However, the intensity to adopt such strategies varies from one household to another depending on different criteria.

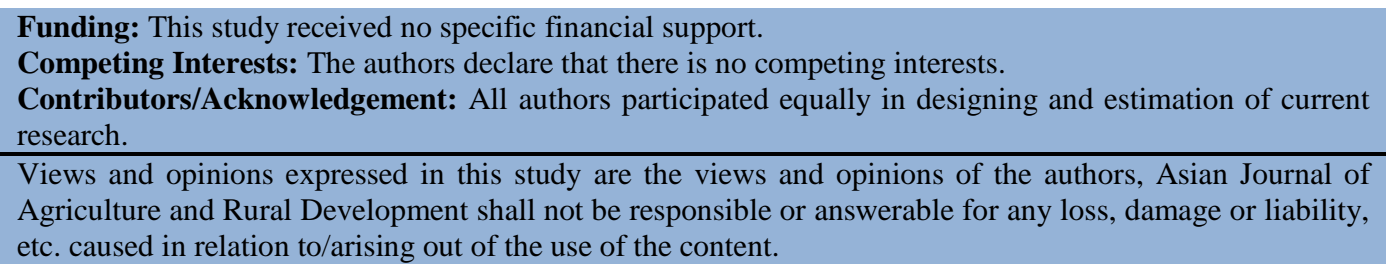

\section{References}

Ashley, C., \& Carney, D. (1999). Sustainable livelihoods: lessons from early experience. DIFD, London.

Barrett, C. B., Reardon, T., \& Webb, P. (2001). Nonfarm income diversification and household livelihood strategies in rural Africa: concepts, dynamics, and policy implications. Food Policy, 26(4), 315-331. https://doi.org/10.1016/S0306-9192(01)00014-8.

Belchar, B., Achdiawan, R., \& Dewi, S. (2015). Forest-based livelihoods strategies conditioned by market remoteness and forest proximity in Jharkhand, India. World Development, 66, 269279. https://doi.org/10.1016/j.worlddev.2014.08.023.

Brocklesby, M., \& Fisher, E. (2003). Community development in sustainable livelihoods approaches - an introduction. Community Development Journal, 38(3), 185-198. Retrieved from www.jstor.org/stable/44258993.

Byron, N., \& Arnold, M. (1999). What futures for the people of the tropical forests? World Development, 27(5), 789-805. https://doi.org/10.1016/S0305-750X(99)00025-X.

Carney, D. (1998). Sustainable rural livelihoods: what contribution can we make? DFID, London.

Carney, D. (2002). Sustainable livelihoods approaches: progress and possibilities for change. DFID, London.

Chambers, R., \& Conway, R. (1992). Sustainable rural livelihoods: practical concepts for the $21^{\text {st }}$ century. IDS Discussion paper, Brighton. 296.

Chandramouli, C. (2011). Rural urban distribution of population. Census of India, Ministry of Home affairs, New Delhi, India extracted on 30/07/2020 from https://censusindia.gov.in/2011-prov-results/paper2/data_files/india/Rural_Urban_2011.pdf

Conroy, C., \& Litvinoff, R. (1988). The greening of aid: sustainable livelihoods in practice. Earthscan Publications, London.

Diniz, F., Kok, K., Hoogstra-Klein, M., \& Arts, B. (2015). Mapping future changes in livelihood security and environmental sustainability based on perceptions of small farmers in the Brazilian Amazon. Ecology and Society, 20(2). Retrieved from www.jstor.org/stable/26270193.

District Census Handbook Kamrup. (2011). Directorate of Census Operations Assam. Census of India, extracted on 1/4/2020 from http://censusindia.gov.in/. 
Dixon, J., Gulliver, A., \& Gibbon, D. (2001). Farming systems and poverty, FAO and World Bank. Rome and Washington DC extracted from http://www.fao.org/3/ac349e/ac349e03.htm.

Ellis, F. (1998). Household strategies and rural livelihood diversification. Journal of Development Studies, 35(1), 1-38. https://doi.org/10.1080/00220389808422553.

Ellis, F. (2000). Rural livelihoods and diversity in developing countries. Oxford University Press, Oxford.

FAO. (2008). Links between national forest programmes and poverty reduction strategies. Forestry Policy and Institutions Working Paper 22. Rome: Food and Agriculture Organisation of the United Nations.

FAO (2020). extracted on 29/072020 from http://www.fao.org/india/fao-in-india/india-at-aglance/en/.

Farmer, B. (1977). Green revolution. McMillan, London.

Gieryn, T. (1999). Cultural boundaries of science: credibility on the line. University of Chicago Press, Chicago, USA.

India Today (2017). New Delhi. Extracted on 29/07/2020 from https://www.indiatoday.in/education-today/featurephilia/story/tribal-education-and-itschallenging-issues-in-india-965832-2017-03-16.

Jansen, H. G. P., Pender, J., Damon, A., Wielemaker, W., \& Schipper, R. (2006). Policies for sustainable development in the hillside areas of Honduras: a quantitative livelihoods approach. Agricultural Economics, 34(2), 141-153.

King, B. (2011). Spatialising livelihoods: Resource access and livelihood spaces in South Africa. Transactions of the Institute of British Geographers, 36(2), 297-313. Retrieved from www.jstor.org/stable/23020819.

Koczberski, G., Curry, G. N., \& Gibson, K. (2001). Improving productivity of the smallholder oil palm sector in Papua New Guinea. RSPAS, Australian National University.

Mary, K. W., Liwenga, E. T., Richard, Y., Kangalawe, M., Ndalhwa, F., \& Robert, K. (2009). Perceived impact of land use changes and livelihood diversification strategies of communities in the lake victoria basin of Kenya. Journal of Agricultural Biotechnology and Sustainable Development, 1(3), 69-78.

Moser, C. (1998). The asset vulnerability framework: Reassessing urban poverty reduction strategies. World Development, 26(1), 1-19. https://doi.org/10.1016/S0305-750X(97)100158.

Neumann, R. P., \& Hirsch, E. (2000). Commercialisation of non-timber forest products: Review and analysis of research. In Bogor, Indonesia: Center for International Forestry Research. Rome: FAO.

Oyinbo, O., \& Olaleye, K. (2016). Farm Households Livelihood Diversification and Poverty Alleviation in Giwa Local Government Area of Kaduna State, Nigeria. Consilience, 15, 219-232. Retrieved from www.jstor.org/stable/26188766.

Sallu, S., Twyman, C., \& Stringer, L. (2010). Resilient or Vulnerable Livelihoods? Assessing Livelihood Dynamics and Trajectories in Rural Botswana. Ecology and Society, 15(4). Retrieved from www.jstor.org/stable/26268197.

Sati, V. P., Wei, D., \& Xue-Qian, S. (2015). Options and strategies for livelihood sustainability in mountainous region of the upper Minjiang River basin, Sichuan Province, China. Spanish Journal of Rural Development, 6, 45-56. https://doi.org/10.5261/2015.GEN3.05.

Scoones, I. (1998). Sustainable Rural Livelihoods: A Framework for Analysis. Institute of Development Studies, Brighton.

Statistical Profile of Scheduled Tribes in India, (2009). Ministry of tribal affairs. Government of India, Chaar Dishayen Printers, Noida, India extracted on 30/07/2020 from https://tribal.nic.in/ST/StatisticalProfileofSTs2013.pdf.

Tittonell, P., Muriuki, A., Shepherd, K. D., Mugendi, D., Kaizzi, K. C., Okeyo, J., Ver-chot, L., Coe, R., \& Vanlauwe, B. (2010). The diversity of rural livelihoods and their influence on soil fertility in agricultural systems of East Africa - a typology of smallholder farms. Agricultural Systems, 103(2), 83-97. https://doi.org/10.1016/j.agsy.2009.10.001. 
Tribal Community Development (2020). Directorate of Distance Education. Alagappa University extracted from https://www.alagappauniversity.ac.in/modules/DDE/uploads/books/sem3/M.S.W/TRIBAL\%20COMMUNITY\%20DEVELOPMENT-34934A.pdf.

Ullah, R., Shivakoti, G., Kamran, M., \& Zulfiqar, F. (2019). Land ownership and catastrophic risk management in agriculture: The case of Khyber Pakhtunkhwa Province of Pakistan. International Journal of the Commons, 13(2), 881-891. doi: 10.2307/26819575.

Walker, T., Ryan, J. (1990). Village and household economies in India's semi-arid tropics. Johns Hopkins University Press, Baltimore, MD.

WCED (1987). Our Common Future: World Commission on Environment and Development. Oxford University Press, Oxford.

Woroniecki, S., Wamsler, C., \& Boyd, E. (2019). The promises and pitfalls of ecosystem-based adaptation to climate change as a vehicle for social empowerment. Ecology and Society, 24(2), doi:10.2307/26796957. Retrieved from www.jstor.org/stable/26796957.

Yamane, T. (1973). Statistics: an introductory analysis. New York: Harper \& Row.

Zenteno, M., Zuidema, P. A., Jong, W. D., \& Boot, R. G. A. (2013). Livelihood strategies and forest dependence: New insights from Bolivian forest communities. Forest Policy and Economics, 26, 12-21. https://doi.org/10.1016/j.forpol.2012.09.011. 